\title{
Organizational E-Readiness Web: A Model for Evaluating E-Readiness of Iranian Commercial Banks In Order To Develop E-Banking
}

\author{
Masoud Keimasi ${ }^{1}$ (corresponding author) \\ Hasti Chitsazan ${ }^{2}$ \\ ${ }^{1}$ Faculty of Management, University of Tehran, Tehran, Iran \\ ${ }^{2}$ Faculty of Entrepreneurship, University of Tehran, Tehran, Iran \\ Email address: keimasi@ut.ac.ir, chitsazan@ut.ac.ir
}

Keywords: e-banking, organizational e-readiness, organizational e-readiness web model

\begin{abstract}
E-banking through mutual benefits for customers and banks has become a necessity in the banking industry nowadays. In spite of this, e-banking has not spread in Iran as it is appropriate.In a general categorization it can be said that E-readiness of banks and environmental ereadiness are two effective factors on development of e-banking which have been referred in different studies some models have been proposed in this regard in macro industries and others. However, no specific model has been proposed for the banks. This paper focuses on the first factor of "organizational e-readiness ".therefore, the main question of this study is that according to which model and toolthe state banks' readiness are evaluated in the field of development of e-banking in the state banks and how much is the current state of e-readiness of banks in this area?
\end{abstract}

Accordingly, a model is presented as an organizational e-readiness web in this research, reviewing the organizational e-readiness evaluation models, and carried out research to identify organizational barriers and motivators of business/ e-banking development. According to the introduced dimensions, the banks enjoy relative readiness for the development of e- banking.

\section{INTRODUCTION}

One of the important questions for the economists who are interested in examining the innovation development behavior and also the marketerswho are interested in anticipating the innovation development trends is which factors affect the acceptance of the new technology? Definitely, the acceptance of electronic banking by the banks is a key prerequisite to convince the customers for utilization of this innovation. But what compels the banks to accept the technology? (Santos and Paners, 1998) On the other hand it is obvious that all the organizations do not intend to accept the electronic commerce alike. The studies reveal that the acceptance of electronic commerce is subjected to attitude of the organization to the electronic commerce technologies, the establishment and tendency to utilization of such technologies in the organization. Hence recognition of the factors which cause the tendency difference of banks to accept electronic banking for empowerment of them for evaluation of their tendency rate and ability in direction of development and utilization of the electronic banking is considered as a necessary matter.

The previous studies reveal that the organizational capabilities affect the acceptance facilitation of information technology. A part of such organizational capabilities is resulted from reaction of the culture and science in the organization and forms the absorption capacity. The acceptance of innovation of technology depends on the tendency for effort to use the methods, processes and the new production systems. (Lin \& Lee, 2005).

On the other hand the viewpoints based on the resources provide the framework concerning the strategy that by means of it, we can recognize and examine the important factors. According to the viewpoints based on the resources, we can recognize and analyze the specifications of the organization which has the better performance in comparison with the other organizations. The resources that make the value for the customers have the tangible and intangible ingredients (Morgan \& Hunt, 1995). 


\section{ORGANIZATIONAL READINESS}

Ginsberg and Venkatraman, 1992 mention that the various managers and organizations have different viewpoint concerning the information technology and this matter resulted from their realization of efficacy of the technology information in the field of their work and the organizational norms in connection with the acceptance of the new information technology. The similar result has been reported in the literature related to the electronic commerce. For example Iacovou etal, 1995 and Crook and Kumar, 1998 mention that the organizations have the different capabilities in the acceptance of electronic commerce. The conducted studies in this field and the available literature have dealt with the interoffice various aspects and their effect on the acceptance of the electronic commerce. However there is no model to deal with the interoffice factors especially in the banking industry so that assessing the banks we can evaluate the capability difference of banks in the development of the electronic banking; hence such questions that utilizing what model we can evaluate the electronic readiness of banks in direction of the development of the electronic banking and how is the current situation of each of the recognized factors?, would be the main questions of this study. Replication tosuch questions in addition to referring to the general models of survey of the organization will refer to the evaluation models of organizational electronic readiness and combining the resulted dimensions with the conducted research in the field of the motives and impediments of development of the commerce and electronic banking, the study conceptual model was designed and according to the same, the evaluation tool of electronicreadiness of the country's banks was presented. The processes of the conducted research have been showed in the figure No. 1. We refer to such processes as follows:

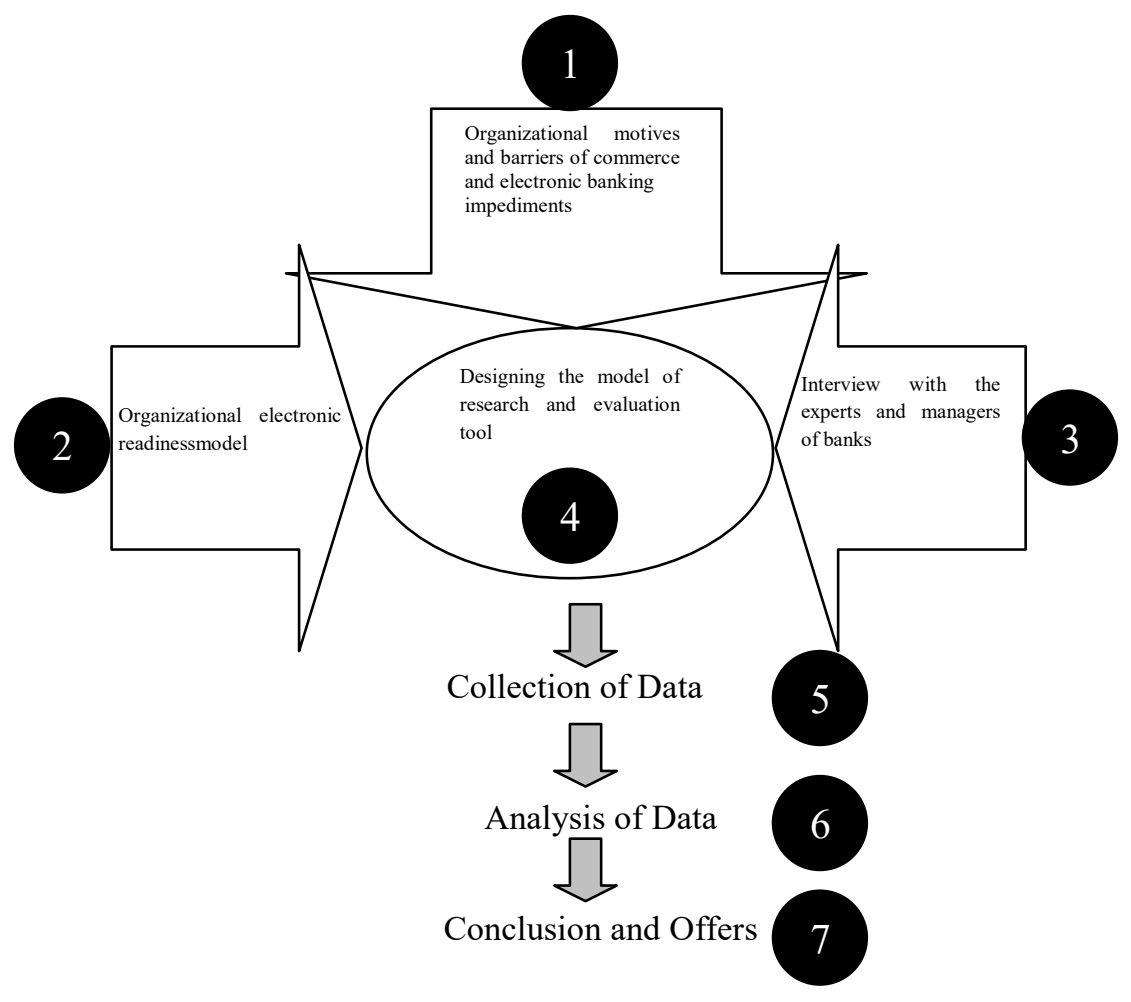

Figure 1: Processes of designing the model

\section{The organizational motives and barriers of development of electronic banking}

The development of electronic banking in the country needs the removal of barriers and difficulties and also reinforcement of the motive and promoter factors. A part of such motives and barriers related to the banks that we deal with them in this section in brief. We have pointed out the organizational barriers and movies of the commerce development firstly and afterward the organizational barriers and movies of development of electronic banking have been investigated in particular. Some of such research has been referred in the figure 2 in brief. 


\begin{tabular}{|c|c|c|}
\hline Researcher & Fieldofstudy & Investigated organizationalfactors \\
\hline Saffu, Kojo et al., 2007 & Acceptance of e-commerce & $\begin{array}{l}\text { Organizational support, information } \\
\text { management, administrative support, assist } \\
\text { in decision-making }\end{array}$ \\
\hline Lee and Edison (2000) & E-readiness Assessment & $\begin{array}{l}\text { Internet readiness, readiness products, } \\
\text { readiness business } \\
\text { resource readiness }\end{array}$ \\
\hline $\begin{array}{l}\text { Quaddus, Mohammad and } \\
\text { Achjari, didi(2005) }\end{array}$ & $\begin{array}{l}\text { Barriers and drivers of } \\
\text { acceptance of e-commerce }\end{array}$ & $\begin{array}{l}\text { Internal stimulus (cost leadership, } \\
\text { reputation, market entry,); internal barriers } \\
\text { (financial, risk, expertise) }\end{array}$ \\
\hline $\begin{array}{l}\text { Shan, Hawley, J. and } \\
\text { Dickerson, K. (2004) }\end{array}$ & Development of e-commerce & $\begin{array}{l}\text { The organization strategies (strategic } \\
\text { approach, product strategy, the } \\
\text { characteristics of organization (size, level } \\
\text { of technological readiness) }\end{array}$ \\
\hline Nath, et al., 1998 & $\begin{array}{l}\text { Barriers of using of e- } \\
\text { commerce }\end{array}$ & $\begin{array}{l}\text { Costs (financial resources), lack of skilled } \\
\text { personnel, lack of confidence and lack of } \\
\text { information }\end{array}$ \\
\hline $\begin{array}{l}\text { Lertwongsatien, et al., } \\
2004\end{array}$ & Acceptance of e-commerce & $\begin{array}{l}\text { Organizational structure, processes, and } \\
\text { information technology }\end{array}$ \\
\hline $\begin{array}{l}\text { Flynn, A. and Purchase, S. } \\
\text { (2000) }\end{array}$ & $\begin{array}{l}\text { Barriers of using of e- } \\
\text { commerce }\end{array}$ & $\begin{array}{l}\text { Lack of business models, poor planning } \\
\text { and organizing, lack pf adequate } \\
\text { knowledge in staff, and lack of } \\
\text { infrastructure, resistance of trading } \\
\text { partners, the time needed for } \\
\text { implementation, lack of interest in } \\
\text { performing, feeling no need for e- } \\
\text { commerce. }\end{array}$ \\
\hline Russell and Hoag, 2004 & IT Compliance & Organizational factors, leadership factors. \\
\hline Chen, 1999 & Development of e-banking & $\begin{array}{l}\text { Ability of bank in operation management, } \\
\text { bank marketing, brand development, } \\
\text { financial market Management. }\end{array}$ \\
\hline Seiulli, 1998 & $\begin{array}{l}\text { Successful implementation of } \\
\text { innovations in products and } \\
\text { services }\end{array}$ & $\begin{array}{l}\text { Lower levels of centralization, the higher } \\
\text { levels the more complex, larger and higher } \\
\text { levels of integration. }\end{array}$ \\
\hline Yousafzai, et al,. 2005 & E-commerce & $\begin{array}{l}\text { Products and services, supported by senior } \\
\text { management, project team, the Web- } \\
\text { friendly, suitable for internal and external } \\
\text { promotion project }\end{array}$ \\
\hline Gurao (2000) & Electronic Banking & $\begin{array}{l}\text { Customer-oriented approach, } \\
\text { service and high reliability, goals, } \\
\text { strategies regarding the business. }\end{array}$ \\
\hline Daniel, 1999 & $\begin{array}{l}\text { The success of micro e- } \\
\text { banking services }\end{array}$ & $\begin{array}{l}\text { Vision, forecasting customer acceptance, } \\
\text { innovation culture, management support, } \\
\text { orientation towards the future, the } \\
\text { willingness to abandon traditional } \\
\text { channels, and the structure of bank. }\end{array}$ \\
\hline
\end{tabular}




\begin{tabular}{|c|c|c|}
\hline Sathye, 1997 & $\begin{array}{c}\text { Development of Internet } \\
\text { Banking }\end{array}$ & Training customers to use internet banking. \\
\hline $\begin{array}{l}\text { Mahdi, Mohamed O. S. } \\
\text { and Dawson, Patrick } \\
\qquad(2007)\end{array}$ & $\begin{array}{l}\text { Development of ICT in } \\
\text { Sudanese commercial banks }\end{array}$ & $\begin{array}{l}\text { Bank managers Collaborate with IT } \\
\text { managers, adequate funding, adequate staff } \\
\text {,formulate the comprehensive banking } \\
\text { policies, considering social-political } \\
\text { challenges, technical challenges. }\end{array}$ \\
\hline Furst et al, 2002 & $\begin{array}{l}\text { Determinants of internet } \\
\text { banking acceptance }\end{array}$ & $\begin{array}{l}\text { Size, age, financial strategy, operational } \\
\text { efficiency, profitability, organizational } \\
\text { factors, business strategy, the overall } \\
\text { security index. }\end{array}$ \\
\hline Deyoung et al,2007 & $\begin{array}{l}\text { Determinants of internet } \\
\text { banking acceptance }\end{array}$ & $\begin{array}{l}\text { Size, financial strategy, operational } \\
\text { performance, business strategy of } \\
\text { organizational variables. }\end{array}$ \\
\hline Corrocher(2002) & $\begin{array}{l}\text { Determinants of internet } \\
\text { banking acceptance }\end{array}$ & $\begin{array}{l}\text { Size, age, operational efficiency, } \\
\text { profitability, branch intensity, business } \\
\text { strategy, innovation. }\end{array}$ \\
\hline
\end{tabular}

Figure 2: Organizational barriers and movies of development of commerce/ electronic banking

\section{EVALUATION MODELS FOR ORGANIZATIONAL ELECTRONIC READINESS}

In addition to the above-said general models that we can use them to analysis the interoffice ingredients, the special models has been provided to evaluate the electronic readiness of organizations which we refer to them as follows:

BEACON Model: This model includes four dimensions of the process, persons, project and technology. The commercial software has been provided to evaluate the structural organizations readiness which shows the results of evaluation in the form of a graphic diagram under the name of Bacon Diagram.

iQNet Model: The evaluation balanced scorecard made by Cisco System Company which is an application program under web that evaluates the ability of organizations in the direction of internet commercial model. This application program evaluates the ability of organization to plan, execute and manage the information technology according to four dimensions of leadership, governance, organizational capabilities and utilization of technology. In order to evaluate the organizational readiness, we can use the questionnaire in this method like Bacon Model.

Verdict Model: Ruikar k. et al. (2006) introduced four key dimensions of an organization including management, technology, process and the persons for electronic readiness.

EMMQ Model: This model which has been prepared with cooperation of Carnegie Mellon University is an evaluation framework for the electronic business. This model includes nine dimensions (strategy, tax and law, technology, systems, security and privacy policy, net evaluation processes, delivery and activities, management of performance, organization and competency) which each of these dimensions includes 10 indicators.

Perceived Electronic Readiness Model: This model has been presented with cooperation of University of Manchester and Oakland University. This model has been presented to investigate the electronic commerce acceptance rate by the organizations in the developing countries that include two sections (organizational perceived electronic readiness and external perceived electronic readiness).

Electronic Government Capacity Test Model: This model includes the main six ingredients (electronic strategy, architecture, management of risk and project, organizational capacities, management of value chain management, performance management) and 25 components. The organizations are evaluated according to the questionnaire which includes 25 factors in this model. (Khanloo, 1382) 


\section{INTERVIEW WITH EXPERTS AND BANKING MANAGERS}

In order to understand the research subject and its richness of dimensions and components completely, the structured interviews with 34 persons of the experts and banking managers related to electronic banking were performed. The used questionnaire included two questions. The first question "what interoffice factors affect the electronic banking development in the country" was an open question. The second question "determine the importance of each of the considered dimensions in electronic banking development according to five-level Likret Spectrum" includes seven components. The purposes of such questions were the investigation of person's views concerning the dimensions resulted from the research literature and also the investigation of possibility of increase of the dimensions and factors. After collection of the views of persons, their views were analyzed using Shannon Entropy and two-sentence tests. The results of this section imply that the importance of all of dimensions was investigated. Therefore a questionnaire including all of the supposed dimensions was designed in the subsequent process. The results of this section have been showed in the data analysis section.

\section{DESIGNING THE RESEARCH MODEL AND TOOLS OF ORGANIZATIONAL READINESS EVALUATION}

In order to investigate interoffice readiness of electronic banking development in the present research with benchmarking from the conducted studies and also the general models of organizational investigation and the electronic readiness evaluation models of organization showed in the previous section, seven factors including senior management, human resource, strategy, structure, technology, organizational culture and financial resources were analyzed.

\section{COLLECTION OF DATE:}

In order to design the organizational electronic readiness evaluation model in this study, a five choices questionnaire (based on Likret Spectrum) according to the mentioned dimensions in the research model including 30 questions was designed. Some of the questions of questionnaire are retrieved from the present questionnaire and the other questions are according to the views of authors of paper and also some of the questions are retrieved from the preliminary interviews with 34 persons from the managers and experts of bank. The evaluated variables and the relevant questions are stipulated in the table 1.

Table 1: Variables and questions of questionnaire

\begin{tabular}{|l|c|}
\hline \multicolumn{1}{|c|}{ Measuring variables } & Number of questions \\
\hline SeniorManagement & 4 \\
\hline Strategy & 6 \\
\hline Organizational Structure & 5 \\
\hline Technology & 3 \\
\hline Human Resources & 6 \\
\hline Organizational Culture & 3 \\
\hline Financial Resources & 3 \\
\hline
\end{tabular}

Population of this study includes all of the managers and experts of state commercial banks related to the electronic banking that from among them, 360 persons were chosen randomly. The banks divided into two categories including governmental and private firstly.

Four banks including Bank Melli, Bank Mellat, Bank Saderat and Tejarat Bank were chosen among the governmental banks; and Parsian Bank, EN Bank, Saman Bank and Karafarin Bank were chosen among the private banks. A questionnaire was distributed between 360 people among the managers and experts of banks who have been working in the information technology section and the projects of banking. Finally 287 completed questionnaires were received and analyzed.

The Cronbach'sAlpha Coefficient is $87.64 \%$ which represents the high stability of this questionnaire. 


\section{ANALYSIS OF DATA}

As mentioned earlier, a questionnaire was distributed firstly between 50 people among the managers and experts of banks in order to recognize the interoffice factors which affect the development of electronic banking and investigate the importance of the supposed seven factors. This questionnaire included two questions:

Question 1: Please refer to the interoffice factors that affect the development of electronic banking. According to the results of Shanon Entropy, the rank of the model ingredients is as follows: The numbers written in the parenthesis represent the importance coefficient of each factor, the rank of organizational factors ingredients are as follows:

Senior Management (24\%), Strategy (22\%), Employees (23\%), Technology (20\%), Organizational Culture (19\%), Organizational Structure (18\%), Financial resource (16\%).

Question 2: Determine the importance of each of the following seven dimensions on the development of electronic banking in the form of five-level spectrum mentioned.

Considering the fact that the five-level spectrum has been used in designing such questions, all the numbers less than 3 and higher than 3 are considered as non-importance (the first group) and importance (the second group), respectively. Since the number 3 is placed in the middle of spectrum, the proportion of test equals to $3 / 5=60 \%$. Therefore we have:

$H_{0}: p \leq 60 \%$ Null hypothesis: The component (considered variable) has no importance from point of view of the experts.

$H_{1}: p>60 \%$ Alternative hypothesis: The component (considered variable) has no importance from point of view of the experts.

Considering the meaningful numbers written in the table (2), we can conclude that all seven ingredients related to the organizational factors are importance in the conceptual model. Therefore the questionnaire including such seven dimensions was designed.

Table 2: The output from the analysis of the binomial test related to the dimensions of organizational readiness

\begin{tabular}{|c|c|c|c|c|c|c|}
\hline \multicolumn{2}{|c|}{ Variables } & category & The number & Observed ratio & Test ratio & Significant value \\
\hline \multirow{3}{*}{$\begin{array}{c}\text { Senior } \\
\text { Management }\end{array}$} & first group & $X<=3$ & 8 & .02 & \multirow{3}{*}{.60} & \multirow{3}{*}{.000} \\
\hline & second group & $X>3$ & 26 & .8 & & \\
\hline & Total & & 34 & 1.0 & & \\
\hline \multirow{3}{*}{$\begin{array}{l}\text { Organizational } \\
\text { Structure }\end{array}$} & first group & $X<=3$ & 15 & .4 & \multirow{3}{*}{.60} & \multirow{3}{*}{.044} \\
\hline & second group & $X>3$ & 19 & .6 & & \\
\hline & Total & & 34 & 1.0 & & \\
\hline \multirow{3}{*}{$\begin{array}{c}\text { Human } \\
\text { Resources }\end{array}$} & first group & $X<=3$ & 9 & .3 & \multirow{3}{*}{.60} & \multirow{3}{*}{.000} \\
\hline & second group & $X>3$ & 25 & .7 & & \\
\hline & Total & & 34 & 1.0 & & \\
\hline \multirow{3}{*}{ Strategy } & first group & $X<=3$ & 10 & .3 & \multirow{3}{*}{.60} & \multirow{3}{*}{.000} \\
\hline & second group & $X>3$ & 24 & .7 & & \\
\hline & Total & & 34 & 1.0 & & \\
\hline \multirow{3}{*}{ Technology } & first group & $X<=3$ & 28 & .8 & \multirow{3}{*}{.60} & \multirow{3}{*}{.005} \\
\hline & second group & $X>3$ & 6 & .2 & & \\
\hline & Total & & 34 & 1.0 & & \\
\hline \multirow{3}{*}{$\begin{array}{l}\text { Organizational } \\
\text { Culture }\end{array}$} & first group & $X<=3$ & 28 & .8 & \multirow{3}{*}{.60} & \multirow{3}{*}{.005} \\
\hline & second group & $X>3$ & 6 & .2 & & \\
\hline & Total & & 34 & 1.0 & & \\
\hline \multirow{3}{*}{$\begin{array}{l}\text { Financial } \\
\text { Resources }\end{array}$} & first group & $X<=3$ & 13 & .4 & \multirow{3}{*}{.60} & \multirow{3}{*}{.008} \\
\hline & second group & $X>3$ & 21 & .6 & & \\
\hline & Total & & 34 & 1.0 & & \\
\hline
\end{tabular}


The results of this final questionnaire are pointed out. In this stage, an exploratory factor analysis is first used for identification of the factors. Regarding the significant number of KMO test $(0.816>0.7)$ and significant number of Bartlett test $(0.00<0.05)$, it can be said that the data are appropriate for execution of factor analysis.

KMO and Bartlett's Test

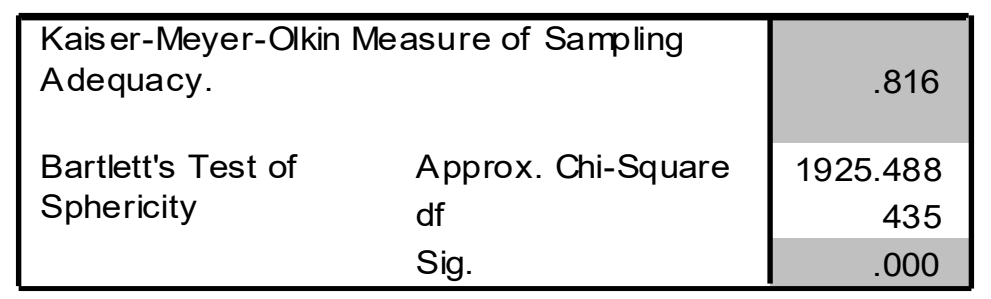

The table of total variance explained (table 3 ) shows that these indicators form eight factors. These factors represent and cover about 65.10 percent of Organizational readiness variance (internal) which in fact shows the construct validity of the questions of this structure. The first factor about 10.16 percent, the second factor about 9.85 percent, the third factor about 8.43 percent, the forth factor about 8.18 percent, the fifth factor about 8.13 percent, the sixth factor about 7.80 percent, the seventh factor about 6.77 percent and the eighth factor is about 5.57 percent of the organizational readiness variance which indicates the amount of factors importance in forming the organizational readiness structure (internal)

Table 3: Table of explained variance

Total Variance Explained

\begin{tabular}{|l|c|r|r|r|r|r|r|r|r|}
\hline \multirow{2}{*}{ Component } & \multicolumn{3}{|c|}{ Initial Eigenvalues } & \multicolumn{2}{c|}{ Extraction Sums of Squared Loadings } & \multicolumn{3}{c|}{ Rotation Sums of Squared Loadings } \\
\cline { 2 - 10 } & Total & $\%$ of Variance & Cumulative \% & Total & $\%$ of Variance & Cumulative \% & \multicolumn{1}{c|}{ Total } & $\%$ of Variance & Cumulative \% \\
\hline 1 & 7.052 & 25.187 & 25.187 & 7.052 & 25.187 & 25.187 & 2.846 & 10.184 & 10.164 \\
2 & 2.353 & 8.403 & 33.590 & 2.353 & 8.403 & 33.590 & 2.758 & 9.851 & 20.015 \\
3 & 1.842 & 6.579 & 40.169 & 1.842 & 6.579 & 40.169 & 2.361 & 8.433 & 28.449 \\
4 & 1.710 & 6.106 & 46.275 & 1.710 & 6.106 & 46.275 & 2.293 & 8.189 & 36.637 \\
5 & 1.536 & 5.485 & 51.760 & 1.536 & 5.485 & 51.760 & 2.277 & 8.133 & 44.770 \\
6 & 1.422 & 5.080 & 56.840 & 1.422 & 5.080 & 56.840 & 2.186 & 7.806 & 52.576 \\
7 & 1.210 & 4.323 & 61.163 & 1.210 & 4.323 & 61.163 & 1.896 & 6.773 & 59.349 \\
8 & 1.104 & 3.944 & 65.107 & 1.104 & 3.944 & 65.107 & 1.612 & 5.758 & 65.107
\end{tabular}

Regarding the concept and nature of indicators forming each factor, the intended names are proposed for each one as follows. Name of the factors has been shown with the question related to each one in the table 4. According to the result, the strategy factor was divided to two strategy factors and strategic correlation. This matter implies that first, the existence of strategy and second strategy correlation of e-banking with macro strategies of bank are the necessary factors for ebanking development.

Table 4: Table of factors

\begin{tabular}{|c|c|c|c|}
\hline Factor name & Factor name & $\begin{array}{c}\text { Percentage ofexplained } \\
\text { variance }\end{array}$ & Questions \\
\hline In1 & SeniorManagement & $62 \%$ & $7-8-10$ \\
\hline In2 & Strategy & $60 \%$ & $14-15-16$ \\
\hline In3 & Human Resources & $59 \%$ & $1-2-3-4-5-6$ \\
\hline In4 & $\begin{array}{c}\text { Organizational } \\
\text { Structures }\end{array}$ & $59 \%$ & $11-12-13$ \\
\hline In5 & StrategicAlignment & $58 \%$ & $27-28-29$ \\
\hline In6 & Technology & $55 \%$ & $24-25-26$ \\
\hline In7 & Organizational Culture & $52 \%$ & $17-18$ \\
\hline In8 & Financial Resources & $38 \%$ & \\
\hline
\end{tabular}


Finally, the first and second orders of confirmatory factor analysis were used in order to investigating the questions and dimensions of organizational readiness through LISREL software.

A) The first order confirmatory factor analysis of the organizational readiness: as shown in figure 3, proportionality indicators of the model implies the appropriateness of measuring model of related variable since the ratio of $\mathrm{K} 2$ to freedom degree is equal to 1.91 and less than permitted amount of 3 and the amount of RMSEA is less than 0.08 .

As shown in figure 4, all the significant number are related to the parameters of the significant model since the significant number of them is higher than 1.96 .

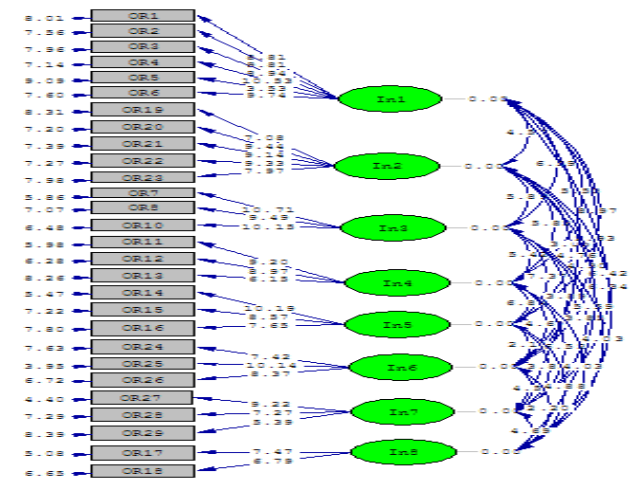

Figure 4: Correlation model among dimensions in the state of significant numbers

B) Second order confirmatory factor analysis of organizational readiness

Proportionality indicators of the model mentioned in figure 5 implies the appropriateness of measuring model of related variable since the ratio of $\mathrm{K} 2$ to freedom degree is equal to 1.91 and less than permitted amount of 3 and the amount of RMSEA is less than 0.08 .

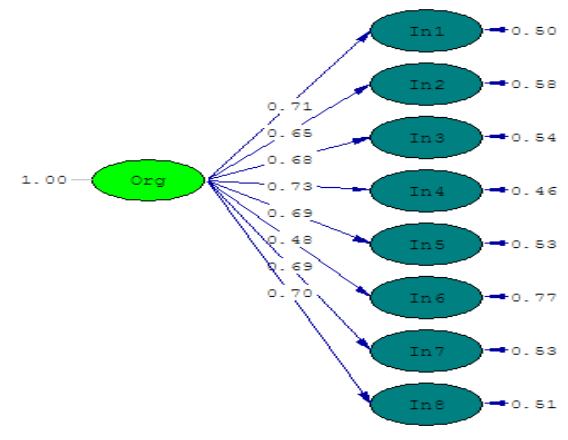
Figure 5: Correlation model between dimensions and concept in the state of standard
estimation

As shown in figure 6, all the significant number are related to the parameters of the significant model since the significant number of them is higher than 1.96 .

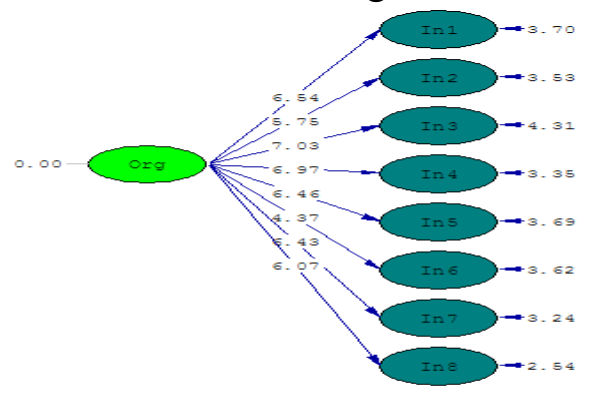




\section{CONCLUSION \& SUGGESTIONS}

The findings of this study provide the researcher and bank experts with a tool for evaluation of organizational readiness of banks for development of e-banking. This tool includes 28 questions which have categorized in the form of eight. These dimensions includes: senior management, human resources, organizational culture, organizational structure, strategy, strategic correlation and financial resources. In fact, development of the e-banking requires knowledge and support of the senior managers, structural appropriateness of banks with technological changes, improvement of knowledge and intention of personnel concerning e-banking service, improvement of culture of admission of change and innovation, compiling strategies and comprehensive plans of e-banking, correlation of the strategies of e-banking with macro strategies of banks and adequate investment and financial resources. However, each of these dimensions is not the same in importance. According to the correlation coefficient, it can be said that senior management, human resources and strategy plays more roles. However, the categorization of these factors requires a separate study. Moreover, this tool can be used for evaluation of internal readiness level of the banks for development of e-banking and it is possible to recognize the strength and weaknesses in this regard.

In addition, the results of studying the existing state of dimensions show that the banks in general enjoy appropriate readiness for development of e-banking. However, in some of the dimensions there are shortcomings. The notable point in table 4 is the gap between the readiness of the bank's senior management and personnel. While senior management of banks has a positive viewpoint on e-banking, the executive body of bank resists development of e-banking due to less knowledge and ability. On the other hand, it seems that the banks has no long-term and comprehensive plan for development of e-banking and their decisions have operational aspect before they deal with this matter according to the strategic viewpoint.

\section{References}

[1] Aladwani, Adel M.(2001) Online banking: a field study of drivers, development challenges, and expectations, International Journal of Information Management, volume 21, pp. 213-225.

[2] Bradley, Laura and Stewart, Kate(2003), A Delphi Study of Internet Banking, Marketing Intelligence and Planning, 21(5), pp. 272-281.

[3] Flynn, A. and Purchase, S. (2000); "Perceptions of Barriers to E-Commerce", ANZMAC Conference, 1st-5th December, Massey University, New Zealand.

[4] Gurau, Calin(2002). E-banking in transition economies: The case of Romania, Journal of Financial Services Marketing Vol. 6, 4, pp. 362-378.

[5] Holland, C.P. and J.B. Westwood, "Product-Market and Technology Strategies in Banking," Communications of the ACM, Vol. 44, No. 5: 53-57, 2001.

[6] Mackay, N., Parent, M. and Gemino, A. (2004); "A model of electronic commerce adoption by small voluntary organization", European Journal of Information Systems, 13 (2), pp. 21-34.

[7] Mahdi, Mohamed O. S. and Dawson, Patrick (2007). The introduction of information technology in the commercial banking sector of developing countries: voices from Sudan, Information Technology \& People Vol. 20 No. 2, pp. 184-204.

[8] Mols, Niels, Peter(1999). The Internet and the Banks' Strategic Distribution Channel Decisions, International Journal of Bank Marketing, 17(6),295-300.

[9] Nath. R., Akmanligil, et al.(1998), Electronic Commerce and the Internet: Issues sproblems and perspectives", International Journal of information Management, 18 (2), pp. 91-101.

[10]Rogers, E.M. (1995), Diffusion of Innovations, 3rd ed., Free Press, New York, NY.

[11]Ruikar K. et al.(2006). VERDICT-An e-readiness assessment application for construction companies Automation in Construction, Vol. 15, pp. $98-110$. 
[12]Russell, Dawn M. and Hoag, Anne M.(2004) People and information technology in the supply chain Social and organizational influences on adoption, International Journal of Physical Distribution \& Logistics Management, Vol. 34 No. 2, pp. 102-122.

[13] Saffu, Kojo et al.(2007). An empirical study of perceived strategic value and adoption constructs: the Ghanaian case, Management Decision,Vol. 45 No. 7, pp. 1083-1101.

[14] Santos, Brian L. Dos and Peffers, Ken(1998),Competitor and vendor influence on the adoption of innovative applications in electronic commerce, Information \& Management, 34, pp. 175184.

[15] Shan, Hawley, J. and Dickerson, K. (2004); "E-commerce Adoption for Supply Chain Management in U.S Apparel Manufacturers", Journal of Textile and Apparel Technology and Management, 4 (1), pp. 1-11.

[16] Tarafdara, Monideepa and Vaidya, Sanjiv D.(2006). Challenges in the adoption of ECommerce technologies in India: The role of organizational factors, International Journal of Information Management 26, pp.428-441.

[17] Turban, E. et al. (2002). Electronic Commerce: Managerial Perspective. Prentice-Hall.

[18] Wang, J. C. and Tsai, K. H. (2002); "Factors in Taiwanese Firm's Decision to Adopt Electronic commerce: An Empirical study", The World Economy, 25, November \& December, pp. 11-45. 